\title{
Privilege revisited: an evaluation of the eye's defence mechanisms
}

\begin{abstract}
Immune privilege has been considered for many years to be an interesting phenomenon associated with certain specialised tissues such as the eye and the brain. In recent years however, it has become clear that the active and passive mechanisms which underpin immune privilege are in fact a form of tissuebased immunological tolerance, perhaps of equal importance in providing defence against antigenic attack as the well established mechanisms based on the thymus (central tolerance) and circulating regulatory cells (peripheral tolerance). It would appear that each tissue possesses a degree of intrinsic immunological resistance which varies depending on the tissues and provides some degree of protection. In some tissues, such as the eye, this is protection from 'danger' has been developed to a high level of sophistication, but at a price. The mechanisms involved are presented in his lecture.
\end{abstract}

Eye (2009) 23, 756-766; doi:10.1038/eye.2008.259; published online 7 November 2008

Keywords: immune privilege; inflammation; tolerance; macular degeneration

\section{Introduction}

I am deeply conscious of the honour which has been afforded to me on receipt of this invitation to deliver the Doyne Lecture, a feeling induced in me when I read down the list of my predecessors.

I have chosen as my subject the topic of Immunological Privilege, an idea which emerged from the early days of study of the immune response to foreign antigens. ${ }^{1-3}$ The concept of immune privilege arose because some tissues did not behave as they were expected to when challenged with foreign antigens, especially alloantigens

(transplantation antigens), and in one sense this atypical response was seen as a curiosity. I hope to show you that what we term immune privilege is more than a curiosity but is central to our understanding of how the organism defends itself from danger.,

The semantics of 'immune privilege'

What is meant by immune privilege? 'Privilege' is defined in the dictionary as follows:

Priv-i-lege $n$ : $\quad$ an advantage, right, or benefit that is not available to everyone;

an exemption; a sanctuary (Shakespeare)

Interestingly, a recent paper by Mellor and Munn ${ }^{6}$ refers to immune privilege in some situations, such as inflammatory granulomas, as providing a sanctuary for infectious organisms, a theme which will be developed later in this lecture. I am not sure that the authors were aware of Shakespeare's use of the word in the same context but they are in good company.

Probably the first use of the word 'privilege' in this context was from the Latin by St Jerome, from where came a common English proverbial saying:

Privilegia paucorum non faciunt legem

(St Jerome: Exposition on Jona; c.342-420)

Lit: the privileges of the few do not make common law:

or, the exception proves the rule

The question, therefore, can be asked: is immunological privilege truly advantageous, is it an exemption from the damaging effects of immune inflammation? Immunity and inflammation are the body's mechanisms of defence against foreign invaders and indeed a certain level of inflammation is seen as 
Table 1 Sites of immune privilege

Sites of immune privilege

Eye, brain (CNS)

Placenta, testis, fetus

Liver, gut, ?pancreas

Tumours

necessary for tissue homoeostasis. ${ }^{7}$ Therefore, although immune privilege is viewed as an evolutionary modification to the immune system aimed at protecting vulnerable but vital tissues, there is an inherent risk in disabling immune defences and there may be a price to pay. ${ }^{8}$

\section{Sites of immune privilege}

Currently there are several sites regarded as immunologically privileged, some more than others (Table 1). However, the initial studies demonstrating immune privilege suggested it was restricted to certain specialized tissues such as the eye. These experiments were performed by Sir Peter Medawar whose fundamental discoveries on transplantation (major histocompatibility; MHC) antigens earned him the Nobel Prize. ${ }^{3,9}$ Medawar was investigating allograft rejection of the skin. He observed that skin homografts when grafted to the anterior chamber of the eye or to the brain were accepted for prolonged periods, if not indefinitely, provided they did not develop a vascular supply by anastomosing with vessels, eg, from the iris. Thus, the basic concept of the immune response, in which there is an afferent arm for antigen delivery and presentation to $\mathrm{T}$ cells and an efferent arm in which activated T cells seek out and destroy foreign antigen, usually at the site of invasion, is dependent on a circulation. Medawar considered the lack of a circulation-explained immune privilege, particularly in the eye.

This idea fitted well with clinical experience at the time. As we know, the cornea is an avascular tissue and since the time of the first non-rejected human corneal graft by Zirm ${ }^{10,11}$ has enjoyed a reputation for acceptance across major histocompatibility differences, ie, without the need for tissue typing. Although opinion on this has changed somewhat, particularly in view of the 5-year results of corneal grafting, ${ }^{10,12,13}$ this privileged view of corneal graft success rates has persisted.

What is it about corneal grafts that gives them a privileged position? Solid tissue allografts are usually rejected because of their content of alloantigens (transplantation antigens). Alloantigens come in several guises, but two forms are relevant to transplantation: major (MHC) and minor histocompatibility antigens. ${ }^{14}$ MHC Class I antigens are expressed on all nucleated cells but usually at low levels, at least in the eye, unless they

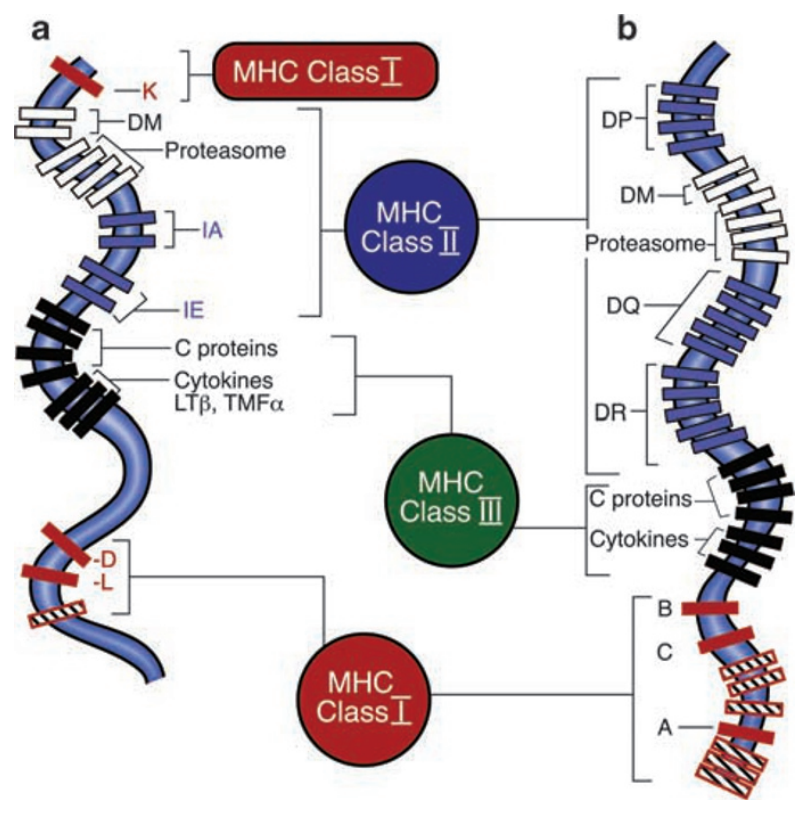

Figure 1 Diagram of chromosomal locations of MHC genes in mouse (a) an man (b). Reprinted with permission from ICP Press: Forrester JV and Kuffova L (2004) Corneal Transplantation An Immunological Guide to the Clinical Problem. (ISBN 1-86094449-3) Imperial College Press, London.

are induced by external stimuli, eg, during inflammation. MHC Class I and Class II antigens are constitutively expressed at high levels in bone marrow-derived leucocytes (Figure 1). Allograft rejection therefore has been attributed to the content of MHC Class I and especially Class II expressing-leucocytes present in the donor graft, some of which are resident in the tissue itself but are also retained in the blood vessels. Lechler ${ }^{15}$ has described these as passenger leucocytes and has attributed graft rejection to the presence of MHC Class II $^{\text {hi }}$-expressing leucocytes. Clinical experience also supports this idea in that matched vascularized grafts survive better than unmatched grafts and the likelihood of survival increases the closer the alloantigen fit between recipient and donor. ${ }^{16,17}$

Streilein et $a l^{18}$ observed that corneal tissue lacked passenger leucocytes. Accordingly, both the lack of blood vessels and MHC Class II alloantigens accounted for the high acceptance rate of unmatched grafts. However, recent studies have shown that the cornea like any other tissue does contain MHC Class II-expressing cells, in both the epithelium and the stroma (Figure 2) although it is not clear whether these resident cells can present antigen (see later). ${ }^{19,20}$ Interestingly some of these cells actually express stem cell markers suggesting that they may be continually renewed in the tissue although most of these cells are replenished from bone marrow turnover. $^{21}$ 

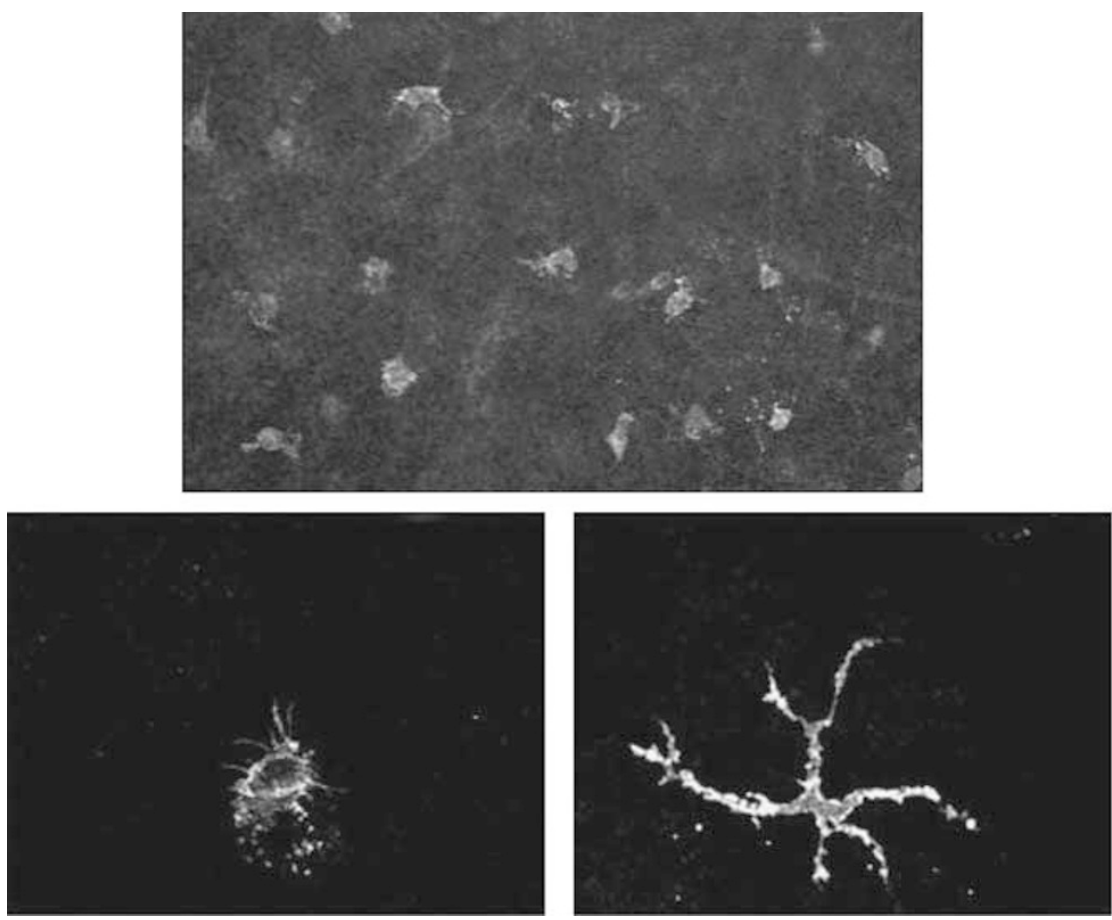

Figure 2 Corneal stromal leukocytes: (Top) CD45 common leukocyte marker, (bottom left): CD34 stem cell marker and (Bottom right): MHC class II marker. Reprinted with permission from Sosnova et al. ${ }^{21}$

\section{Corneal grafts are rejected but do so by indirect allorecognition}

In spite of the fact that the cornea does contain MHC Class II-expressing leucocytes, the evidence that corneal grafts in humans and mice are at least partly protected cannot be denied. We all recognize that skin grafts are rejected in 7-10 days but even in experimental mice rejecting corneal grafts take 15-21 days to fail and some grafts (around 20-50\%) depending on the strain are accepted indefinitely. ${ }^{22}$

In part, this is due to the mechanism of rejection. Untreated solid organ grafts are rejected acutely by a process termed direct allorecognition in which viable passenger leucocytes, using donor MHC Class II, act directly as the cells which present antigen to the recipient T cells. ${ }^{10}$ In most vertebrates, there are many $\mathrm{T}$ cells (about $4-5 \%$ of the total T cells) which can respond to alloantigen in this way. However, it has been shown in many studies that corneal graft rejection occurs by indirect allorecognition. ${ }^{23-29}$ In this process, cells presenting the antigen are derived from the recipient, not the donor. Recipient MHC Class II positive cells infiltrate the donor graft and take up alloantigen (donor MHC Class I, II, as well as minor antigens) and present these antigens to recipient $T$ cells. Whether the recipient $T$ cells respond depends on many factors such as the number, amount, and immunogenicity of each antigen. In this regard, the mechanism is exactly the same as the response of the organism to foreign antigen and is under the same constraints. For instance in the response to herpes virus it has been shown that the immune response is restricted to a select number of highly immunogenic viral envelope proteins. ${ }^{30}$ In fact, the strongest alloantigens in the cornea appear to be minor or non$\mathrm{MHC}$, as yet unidentified, antigens whereas the response to $\mathrm{MHC}$ antigens is less. ${ }^{26}$ In human corneal graft this is reflected in the relatively beneficial effect of matching for blood group antigens (a non-MHC set of antigens) whereas the question of matching for MHC antigens remains controversial and awaits the outcome of a definitive study (in progress).

Definitive evidence for the central role of recipient antigen-presenting cells in corneal graft immunity has been provided in a recent study in which host antigen presenting cell-associated cornea-derived antigen was delivered to the draining lymph node and induced antigen-specific T-cell activation ${ }^{20}$ (Figure 3).

\section{Does the eye have a lymphatic drainage?}

As it became clear that several tissues which acted as privileged sites contained a vasculature, the concept developed that the brain and the eye were particularly 'privileged' because they did not have a lymphatic vessel 


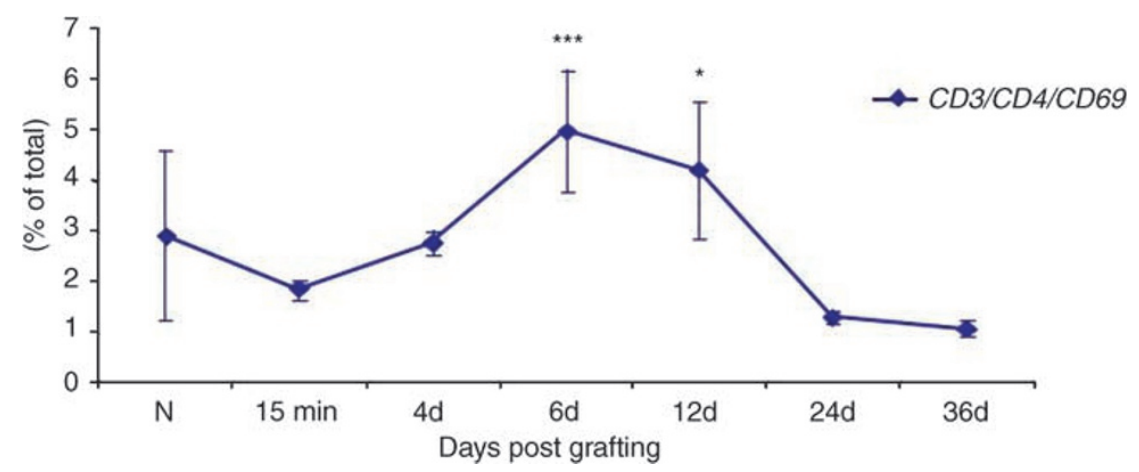

Figure 3 Levels of activation markers (CD69) on antigen-specific CD4 T lymphocytes peak in the draining lymph node 6 days after grafting in the mouse. Reprinted with permission from Kuffova et al. ${ }^{20} P<0.05 ;{ }^{* * *} P<0.01$.

system. In fact, early literature on the brain had shown that there was communication between the brain and the superficial cervical lymph nodes via the nasal cribriform plate which has recently been confirmed. ${ }^{31}$ Similarly, a drainage route from the eye to the submandibular lymph node has been demonstrated, ${ }^{32}$ although the precise lymphatic channels have not been completely charted ${ }^{33,34}$ despite the recent studies showing that there are many cells in the eye and the orbit which express lymphatic markers. ${ }^{35}$ The most definitive evidence that there must be a lymphatic drainage from the eye comes from studies which show that previous removal of the submandibular lymph node prevents corneal graft rejection..$^{36}$ This applies both to grafts in naive mice as well as high risk, vascularized grafts. ${ }^{37}$ In addition, recent studies have shown that soluble antigen placed into the anterior chamber of the eye is distributed to many lymph nodes, even those as distant as the mesenteric nodes. Soluble antigen from the cornea is less widely distributed but reaches the submandibular node in remarkably short time (30 min, experiments in progress) strongly indicating the presence of preformed lymphatic channels. Alternatively, it is just possible that the many aligned Lyve- $1+$ cells present in the eye and orbit ${ }^{35}$ rapidly form connections and convert to channels when activated by an inflammatory stimulus.

In summary, for this part of my presentation, the kinetics of corneal graft rejection can be considered as follows: under normal resting conditions there is a steady migration of antigen-presenting cells into the cornea from the bone marrow (Figure $4 \mathrm{a}, \mathrm{b}$ ); after grafting, there is a massive recruitment of fresh bone marrow cells which pick up antigen and transfer it to the lymph node where they activate antigen-specific T cells; these cells, which normally circulate in a naive state through the secondary lymphoid tissues, once activated target or 'home' to the cornea where they recruit tissue damaging macrophages and other cells. This process begins immediately after grafting (minutes) and only becomes
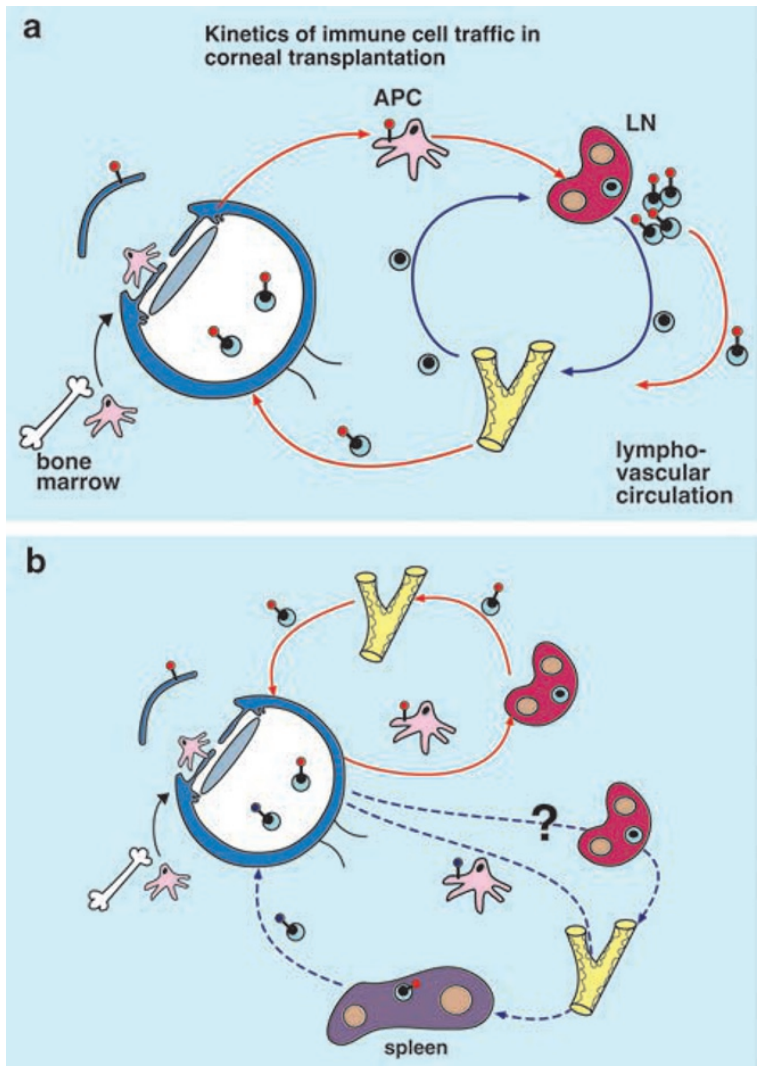

Figure 4 Diagram of kinetics of dendritic cells and T cells after corneal grafting. (a) immediately after grafting, there is induction on trafficking of bone marrow-derived dendritic cells to the cornea where they pick up antigen (red marker) and convert it in to manageable peptide, which they transport and present to $\mathrm{T}$ cells in the draining lymph node. The T cells then traffic back to the cornea where in the activated state they secrete cytokines and attract in many additional cells, such as macrophages, which then causes tissue damage. (b) antigen-presenting cells may also traffic to the spleen and to other non-draining lymph nodes where they receive immuosuppressive signals and exert inhibitory/regulatory effects on the T-effector cells. Reprinted with permission from ICP Press: Forrester JV and Kuffova L (2004) Corneal Transplantation - An Immunological Guide to the Clinical Problem. (ISBN 1-86094-449-3) Imperial College Press, London. 
clinically important when a certain threshold of T-cell activation and recruitment is reached. This is when rejection occurs and this process requires several rounds of T-cell activation to occur. In the meantime, the properties of the privileged tissue (see below) try to prevent this and what determines whether rejection or acceptance of the graft occurs is how this balance between tolerance vs immunity is tipped. In cases of high risk corneal graft, such as herpes simplex keratitis where the immune system has been already activated and there is a strong innate immune response, it is likely that the balance is tipped in favour of immunity rather than tolerance, ie, rejection rather than acceptance of the graft.

\section{What is ACAID and what is its relationship to immune privilege?}

Several years ago Streilein and Kaplan demonstrated a phenomenon which occurred when foreign antigens were placed into the anterior chamber of the eye. ${ }^{38,39}$ When experimental animals were then rechallenged with the same antigen some time later in the skin, the normal immune response (delayed type hypersensitivity in this case) was suppressed. The failure to respond was antigen specific in that there was a normal response to 'third party' antigens. The immune suppression (or induced tolerance to the specific antigen) was not complete because antibodies to the specific antigen could be detected. They termed this phenomenon anterior chamber associated immune deviation (ACAID).

A re-reading of Medawar's original paper ${ }^{2}$ shows that he had already observed ACAID. Orthotopic skin grafts, which he performed in recipients of same-donor skin grafts previously placed into the anterior chamber of the eye, were fully accepted whereas third party grafts were rejected. Thus antigens placed in the anterior chamber of the eye induce a form of tolerance which bizarrely can prevent immunologically mediated disease as has been shown recently in an experimental model of allergic asthma. ${ }^{40}$

In evolutionary terms it is difficult to see what teleological value to survival ACAID has. It is possible, and is explained in this way, that certain self-antigens such as those in the eye have been 'ignored' by the immune system during development of tolerance rather than being actively tolerized. As a result, exposure of such antigens in the adult to the uneducated immune system would lead to an overwhelming immune response because they would be seen as foreign antigens rather than self-antigens. In essence this is just another way of describing 'sequestration' of antigens, a long-held concept in the field of immune privilege. 9 Perhaps ACAID is an in-built mechanism to prevent or at least suppress this event.

\section{What is required to activate a $T$ cell?}

Activation of $\mathrm{T}$ cells by specific antigen has certain prerequisites:

(1) Opportunity and access (to the antigen): either the $T$ cells must get to the antigen or the antigen must get to the T cells.

(2) A properly processed antigen: antigens are mostly proteins with many potential immunogenic (as well as non-immunogenic) segments known as epitopes. Protein antigens are digested into peptides containing epitopes and if they are the right size and shape they will bind to the MHC Class I and II molecules, expressed on the surface of the cell, which digested them to peptides, and the MHC-peptide package will be presented to the T cells which will then be activated.

(3) A properly presented antigen: as we all know, presentation is all about style. It is not sufficient for the antigenic peptide to be wrapped up in the MHC molecule and be presented nakedly to the T cells. It requires other supporting molecules to dress up the immunogenic antigen for presentation (costimulatory molecules and cell adhesion molecules) which form an 'immunological synapse' with T cell. ${ }^{41}$ Actually, presentation of the antigen without the supporting cast leads to tolerance rather than immunity. ${ }^{42}$

Is immune privilege simply a failure of the immune system to access the antigen ('sequestration'; 'immunological ignorance')?

Since the concept was first formulated, blood-tissue barriers have been proposed as the main blockade for

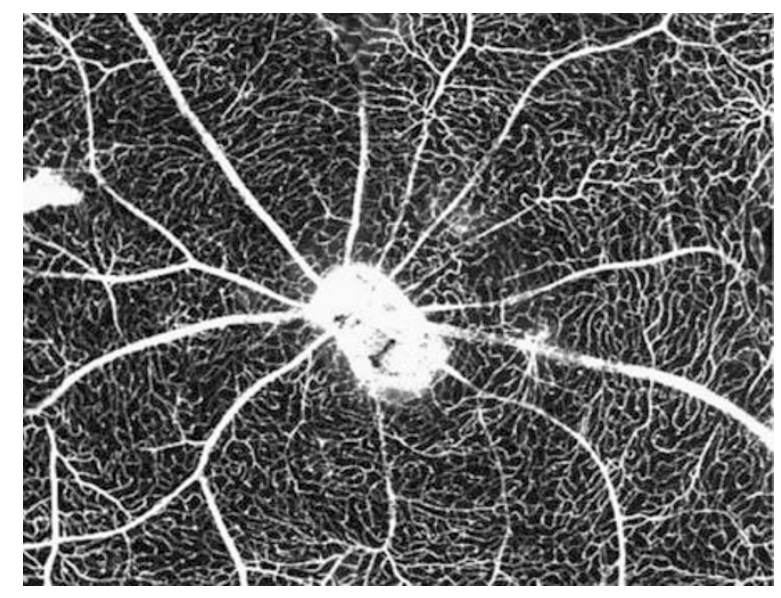

Figure 5 Flat mount of retina from mouse eye, after intravenous injection of fluorescent dye, showing tight blood retinal barrier (no dye leakage) in fine capillary network (with thanks to $\mathrm{H} \mathrm{Xu}$ ). 


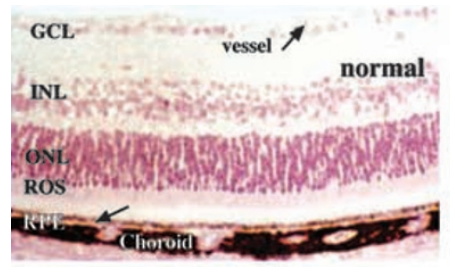

EAU in the B10.RIII mouse induced by $50 \mu \mathrm{g}$ IRBP in CFA intradermal plus Ptx ip. 12d post immunisatn; H\&E.

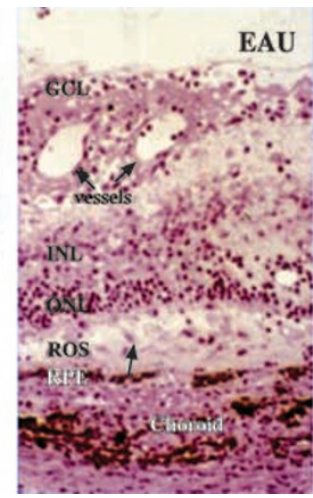

Figure 6 Histology of experimental autoimmune uveoretinitis (EAU) in the mouse. Both panels were photographed at same magnification. The retina with EAU is severely swollen because of leakage from the breached blood-retinal barrier.

access of T cells to antigens in immune privileged sites. In fact, the tight blood-retinal and blood-brain barriers have long been considered a sufficient explanation for immune privilege. Evidence for a barrier to the passage of small molecules was originally observed in the early days of delineating the circulatory pathways using cationic coloured dyes. ${ }^{43}$ It was noted that although there was rapid perfusion of most of the systemic circulation, dyes did not rapidly permeate the brain vasculature although they did reach the brain in time. The barrier is now known to be due to tight junctions (TJs) between endothelial cells, composed of specific proteins such as occludin and claudin ${ }^{44}$ and molecular sizing experiments have shown that TJs are effective barriers to even small molecules of $10 \mathrm{kDa}$ or less ${ }^{45}$ (Figure 5).

However, BRB is not an effective barrier to cells. Firstly, it is readily breached in inflammation such as autoimmune uveitis as has been demonstrated experimentally (Figure 6). ${ }^{46-48}$ However, even here it is selective because only certain subtypes of T cell, such as interferon gamma producing Th1 cells, readily cross the retinal vessels. ${ }^{49}$ In addition, even when cells cross the vessels, they require to be activated systemically and to circulate for some time before they cross the vessels into the retina. ${ }^{50}$ This applies to both T cells and monocytes and suggests that penetration of the barrier in inflammation requires the vessel wall to be 'made ready' for transendothelial migration, probably by weakening of the TJs. This may occur by repetitive contacts between the activated $\mathrm{T}$ cell and the endothelial cells and require antigen-specific signalling events in the endothelial cells, an area which requires further research.

Even in the resting state, cells can cross the BRB. In fact, the retina contains a population of bone marrowderived cells, known as microglia, which increase in number with age ${ }^{51}$ and are constantly replenished from precursor cells. ${ }^{52}$ In order to reach the retinal parenchyma, microglia must penetrate the BRB and clearly do so at a constant low frequency throughout life. Furthermore, recent studies have revealed a small population of professional antigen-presenting cells (dendritic cells), which express high levels of MHC Class II and reside in the retinal periphery and around the optic nerve (Figure 7). The function of these cells is unclear but their location suggests they are gatekeepers controlling entry of $\mathrm{T}$ cells to the retina. In fact, experiments in which activated $\mathrm{T}$ cells have been intravenously administered to mice developing uveitis show that these cells reside at the initial site of contact between the $\mathrm{T}$ cell and the antigen-presenting cell. ${ }^{53}$ Perhaps in the normal physiological state these peripheral antigen-presenting cells promote tolerance ('privilege') rather than immunity. It is interesting to note that many types of chronic posterior uveitis begin with lesions around the optic nerve or in the region of the pars plana/retinal periphery. ${ }^{54}$

\section{What activates $\mathrm{T}$ cells in the periphery?}

We have seen that although a BRB exists, particularly to small molecules, it is not a very effective barrier to the passage of cells. However, we have also noted that in order to cross the barrier they must be activated and in order to cause damage to the tissues they must have been activated to specific antigen, ie, in the case of posterior uveitis, usually retinal antigens. ${ }^{54}$ This means that the T cells must be primed to retinal antigen before they get into the eye even it they are further activated inside the tissue. So antigen must leak out of the retina and get to the T cells?

Recent studies in many tissues have shown that shedding of tissue antigens as part of normal cell turnover and death is a physiological tissue renewal process. Apoptotic cells with self-antigens are endocytosed by resident tissue bone marrow-derived cells and transported to the draining lymph nodes where they are processed and presented to dendritic cells. In the absence of inflammation and activation of the innate immune system, eg, via Toll receptors and other pathogen-associated molecular patterns, ${ }^{55}$ presentation of self-antigens induces regulatory $\mathrm{T}$ cells and anergy which promote tolerance and prevents autoimmunity. ${ }^{56-58}$ When this process is disrupted, for instance in association with infection or inflammation, bystander autoreactive T-cell activation takes place and the risk of autoimmunity is increased provided the activated $\mathrm{T}$ cell can gain access to the tissue (cross the barrier).

For many tissues this process has been shown, eg, for $\beta$-cell antigens from the pancreas. ${ }^{59,60}$ However, in the retina this has been much more difficult to demonstrate. 

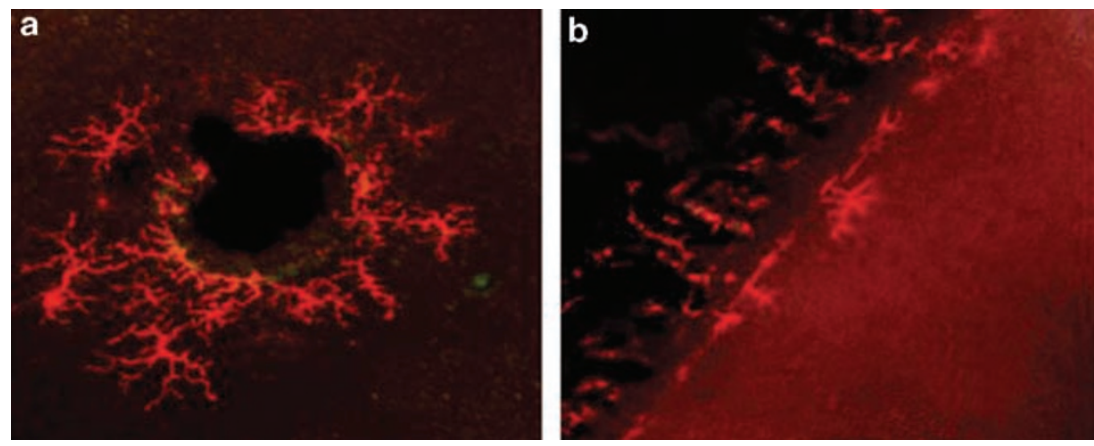

Figure 7 MHC class II+ dendritic cells at the retinal border zones (a) around the optic nerve (b) at the retinal periphery near the ciliary body. Reprinted with permission from $\mathrm{Xu}$ et al. ${ }^{53}$

Recently we have generated in transgenic mouse in which the foreign antigen, hen egg lysozyme (Hel) has been expressed as a neo (self)-antigen in the retina under control of the promoter for interphotoreceptor retinal binding protein. ${ }^{61}$ When these mice are interbred with a second transgenic mouse in which the majority of the $\mathrm{T}$ cells express a receptor which is specific for Hel, they develop spontaneous uveoretinitis. If the above hypothesis is correct, the T cells must have been activated in the peripheral lymph nodes or spleen before they crossed into the retina to cause disease. However, to date we have not been able to find evidence of peripheral T-cell activation although further studies are in progress. In studies using a rat model of uveoretinitis we have further researched this question by transferring activated T cells and tracking them to the tissues. In these experiments we have shown that there is an accumulation of antigen-specific $T$ cells to the iris and ciliary body, which also express retinal antigen (in this case retinal $\mathrm{S}$ antigen) where they appear to undergo further activation and proliferation (K Williams, in preparation). Such cells would have ready access to the peripheral retina and be primed to initiate uveitis and break the 'privilege'.

\section{Is there anything special about ocular immune privilege?}

Our story so far relates that in order to cause inflammation and tissue damage either to self- or foreign antigens, cells of both the innate and the adaptive immune systems require to be activated in the periphery and then to cross the blood-tissue barrier, whereas in the case of $\mathrm{T}$ cells they are further or fully activated to cause disease. This process is well understood for infectious disease where for instance, in viral infections after a period of viraemia and specific T-cell induction in the lymph nodes, the antigen-specific T cells home to the site of original infection (for instance mucosal epithelial cells) and kill off the infected cells. ${ }^{62}$
There is no reason to believe that the same process does not occur for autoimmune disease. After bystander activation in the periphery, the activated T cells home to the tissue-specific location of the self-antigen and initiate killing. In the case of diabetes this is mediated by CD8+ $\mathrm{T}$ cells directly killing cells expressing the 'MHC Class I $\beta$-cell peptide' package, $^{60}$ whereas for rheumatoid arthritis killing is mediated indirectly through activated macrophages recruited by CD4 $+\mathrm{T}$ cells, themselves activated by the 'MHC Class II-collagen peptide' package. ${ }^{63,64}$

Why then are we not constantly at risk of developing autoimmune disease? This depends on the properties of the tissue and their ability to inhibit T-cell access to the tissue, either through functional or physical barriers, in other words by the relative degree of 'immune privilege' particular to that tissue. For some tissues these barriers are developed to a high level and there is a hierarchy of relative privilege, which the eye and the brain lead (see above). Recently, the immunoregulatory functions of tissues have been brought to centre stage and has been developed as a concept equal in importance to the canonical central and peripheral tolerance mechanisms, rehearsed ad infinitum by immunologists. ${ }^{4,65-67}$ In reality, tissue immunregulatory properties are another way of describing immune privilege, ie, ways in which the tissues and its secreted products can control immune responses. It is even possible to induce immune privilege in certain sites such as in accepted grafts or in tumours, where $T$ regulatory cells are induced by the tissue. ${ }^{68}$ In tumours, this form of 'privilege' can be harmful to the organism in the long run by promoting growth of the tumour and metastases. ${ }^{69}$

For the eye, many specific tissue-based immunoregulatory mechanisms have been described, most of which disable or deviate the immune response, but some of which can paradoxically promote inflammation (Table 2). Some appear to be 'master regulators' such as TGF $\beta$ which is a prime 
Table 2 Immumodulatory factors in the retina, providing 'privilege'

\begin{tabular}{|c|c|c|c|c|c|}
\hline Type of factor & Example & $\begin{array}{l}\text { T-cell } \\
\text { function }\end{array}$ & $\begin{array}{l}\text { Macrophage } \\
\text { activity }\end{array}$ & $\begin{array}{l}\text { Antigen } \\
\text { presentation }\end{array}$ & $\begin{array}{l}\text { Cell } \\
\text { killing/apoptosis }\end{array}$ \\
\hline Neuropeptide & $\begin{array}{l}\text { VIP, PACAP } \\
\text { CGRP, Melanocortin } \\
\text { Substance P }\end{array}$ & Inhibits & Inhibits & & \\
\hline Neurotransmitter & GABA, glycine & Inhibits & Promotes & & \\
\hline Cytokine & TGFb, IL10 & & & & \\
\hline Chemokine & MCP-1, SDF-1 & & Promotes $^{\mathrm{a}}$ & & \\
\hline Membrane ligand & $\begin{array}{l}\text { FasL, CD200 } \\
\text { TRAIL, APRIL, }\end{array}$ & & & & Promotes \\
\hline Membrane receptor & TLRs & ?Inhibits & Promotes & & \\
\hline Cellular enzymes & IDO, L-arginase & Inhibits & & Inhibits & Promotes \\
\hline MHC protein & Qa-1 & & & Inhibits & \\
\hline Prostaglandins & $\begin{array}{l}\text { PGE2 } \\
\text { LTAb4 }\end{array}$ & Inhibits & & Inhibits & \\
\hline Cannabinoids & & Inhibits & & ?Inhibit & ?Promotes \\
\hline Free radical & Peroxynitrate & & Promotes & Inhibits & Promotes \\
\hline
\end{tabular}

aScavenger activity?

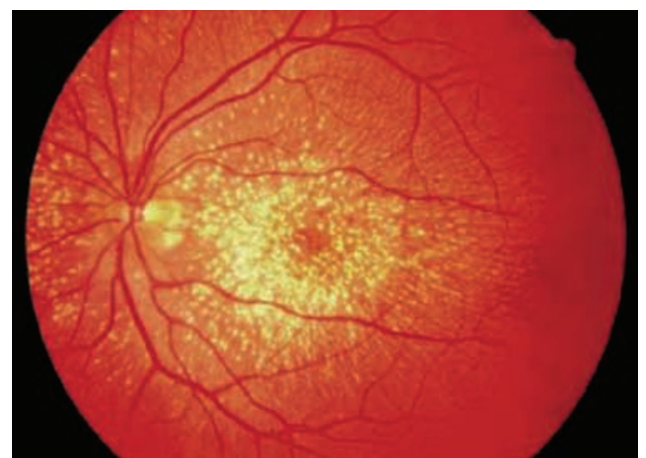

Figure 8 Fundus photograph of Doyne's 'Honeycomb' choroditis. Reprinted with permission from the Geneva foundation for Medical Education website: http://www.gfmer.ch/genetic_diseases_v2/ gendis_detail_list.php?cat3 $=448$.

immunosuppressive cytokine, but even this cytokine in another context can induce inflammatory disease via Th17 cells. $^{70,71}$

\section{Immune privilege and macular degeneration}

I have been quite remiss so far in making no reference to my eponymous Master Robert Doyne. I will not reiterate details of his life history and attachment to Oxford, which have been recorded by many previous Doyne lecturers. Rather I wish to draw attention to the condition that he described, Doyne's honeycomb choroiditis (Figure 8). The inexorable forward march of human genetics has revealed that this condition is due to a defect in the EFEMP-1 (fibulin3), in which there is an aminoacid substitution of arginine for trytophan at position $345 .^{72-74}$ Fibulin3 is one of a family of proteins present in basement membranes and elastic extracellular matrix such as the Bruch's membrane and the choroid of the eye. They appear to operate an organizational role in the supramolecular structure and matrix arrangement of well-recognized basement membrane proteins such as tropoelastin, fibronectin, fibrillin, and especially proteoglycans. ${ }^{75,76}$ The result of this mutation is that there is an accumulation of waste products below the retinal pigment epithelium in the form of drusen. Drusen $^{77-79}$ are the hallmark of age-related macular degeneration (AMD) in humans, the commonest cause of blindness in the developed world and one in which a low grade inflammatory process has been identified, linked to defects in complement genes. ${ }^{80-83}$

Drusen also occur in certain mouse models of AMD in which genes regulating the function and behaviour of macrophages are defective. ${ }^{80,84-88}$ This results in abnormal neovascular responses or in atrophic degenerative retinal disease.

The nature and genesis of drusen are not clear. It is suspected that drusen are deposits of material, which have not been properly cleared by the phagocytic machinery of the RPE cell. Aging RPE cells can be visualized in patients as increased autofluorescence of the retina. However, in the mouse and probably the human also, autofluorescent spots are also caused by activated microglia, stuffed full of lipofuscin. ${ }^{51}$ The relationship between these autofluorescent cells and drusen is not clear at present but it is possible that drusen represent cellular debris (secreted or otherwise) which cannot be cleared by the normal phagocytic cells of the retina. As indicated above, dying cells in the process of cell turnover are normally removed by resident macrophages and other tissue cells. What happens when 
this process fails is not known but it is not difficult to envisage that accumulation of waste products in the tissue will in time induce an inflammatory response to remove the material. In fact one can take this idea further, and consider that perhaps a regulated low level of inflammation is required to remove tissue debris. In the eye, this low grade inflammatory response may be regulated (? or promoted) by the tissue-generated immune privilege, ie, the imunoregulatory microenvironment (see Table 2), for better or worse. ${ }^{8}$ This homoeostatic balancing act can be considered to be fine tuned by the properties of the tissue, and it is still not clear whether AMD, and its several manifestations (wet, dry, RPE rips, drusen, etc) are the result of too much or too little inflammation. ${ }^{89}$ It may depend on the precise conditions in each individual case. While we attempt to unravel the inflammatory mechanism of AMD, we might reflect on what we want to do once we know what happens. Should we promote or prevent the inflammatory process?

\section{Conclusion}

In conclusion, I have laid before you a revised version ocular 'immune privilege', which draws attention to the fundamental importance of this tissue-centred immunoregulatory mechanism. Is immune privilege a form of tolerance? Immunologists will debate this, and the semantics thereof, for many years to come. What is clear however, is that immune privilege can no longer be regarded as an immunological curiosity; that it is possible to induce or inhibit immune privilege for clinical benefit for instance in graft rejection, tumour control, and macular degeneration; and that there are potential dangers also in doing so, for instance, inadvertently promoting tumour growth or worsening tissue damage in macular degeneration. For the eye, immune privilege is probably beneficial, but as Rachel Caspi has pointed out there may be a price to pay if inflammation gains the upper hand. ${ }^{8}$

The last word goes to Elizabeth Simpson who stated that there has been a 'convergence of mechanisms controlling both induced tolerance and privilege,' ie, the eye is teaching us how to devise ways to restore natural tolerance and has been doing so for more than 100 years. $^{90}$

I have many colleagues to thank for contributing in many ways to this work over many years, without whom this overview would not have been possible. Their names are listed in the acknowledgments below. Particular thanks go to Dr Heping Xu, Dr Lucia Kuffova, and Professor Andrew Dick for advice and contributions over many years.

\section{Acknowledgements}

I thank Lucia Kuffova, Heping Xu, Heping Xu, Jarka Plskova, Delyth Reid, Mei Chen, Magda Sosnova, Kimmo Makinen, Noemi Lois, Andrea Vitova, Hui Rong Jiang, Lei Liu, Annie Lau, Zexu Dang, Janet liversidge, Li Cai, A Mannivannan, Aihua Goa, Isabel Crane, Bob Cheng, Liz Muckersie, Linda Duncan, Martin Filipec, Andrew Dick, Vladimir Holan, Richard Cornall, Janson Leung, and Teresa Lambe for their contributions to this work.

\section{References}

1 Billingham RE, Brent L, Medawar PB. Acquired tolerance of skin homografts. Ann N Y Acad Sci 1955; 59: 409-416.

2 Medawar PB. Immunity to homolgous grafted skin. Br J Exp Pathol 1948; 29: 58-69.

3 Medawar PB. The immunology of transplantation. The Harvey Lecture's. Academic Press: London, 1956, pp 144-176.

4 Matzinger P. An innate sense of danger. Ann N Y Acad Sci 2002; 961: 341-342.

5 Matzinger P. The danger model: a renewed sense of self. Science 2002; 296: 301-305.

6 Mellor AL, Munn DH. Creating immune privilege: active local suppression that benefits friends, but protects foes. Nat Rev Immunol 2008; 8: 74-80.

7 Carson MJ, Doose JM, Melchior B, Schmid CD, Ploix CC. CNS immune privilege: hiding in plain sight. Immunol Rev 2006; 213: 48-65.

8 Caspi RR. Ocular autoimmunity: the price of privilege? Immunol Rev 2006; 213: 23-35.

9 Medawar PB. Immunological tolerance. Nature 1961; 189: 14-17.

10 Forrester JV, Kuffova L. Corneal Transplanation: An Immunological Guide to the Clinical Problem. Imperial College Press: London, UK, 2003.

11 Zirm E. Eine erfolgreich totale Kertoplastik. Albrecht Von Graefes Arch Ophthalmol 1906; 64: 580.

12 Williams KA, Muehlberg SM, Lewis RF, Coster DJ. How successful is corneal transplantation? A report from the Australian Corneal Graft Register. Eye 1995; 9(Part 2): 219-227.

13 Williams KA, Muehlberg SM, Lewis RF, Coster DJ. Longterm outcome in corneal allotransplantation. The Australian Corneal Graft Registry. Transplant Proc 1997; 29: 983.

14 Fischer GF, Mayr WR. Molecular genetics of the HLA complex. Wien Klin Wochenschr 2001; 113: 814-824.

15 Lechler RL, Batchelor JR. Restoration of immunogenicity to pssenger cell-depelted kidney allografts by the addition of of donor strain dendiritic cells. J Exp Med 1982; 155: 31-41.

16 Sheldon S, Poulton K. HLA typing and its influence on organ transplantation. Methods Mol Biol 2006; 333: 157-174.

17 Opelz G, Wujciak T, Dohler B, Scherer S, Mytilineos J. HLA compatibility and organ transplant survival. Collaborative Transplant Study. Rev Immunogenet 1999; 1: 334-342.

18 Streilein JW, Toews GB, Bergstresser PR. Corneal allografts fail to express Ia antigens. Nature 1979; 282: 326-327.

19 Huq S, Liu Y, Benichou G, Dana MR. Relevance of the direct pathway of sensitization in corneal transplantation is dictated by the graft bed microenvironment. J Immunol 2004; 173: 4464-4469. 
20 Kuffova L, Netukova M, Duncan L, Porter A, Stockinger B Forrester JV. Cross presentation of antigen on MHC class II via the draining lymph node after corneal transplantation in mice. J Immunol 2008; 180: 1353-1361.

21 Sosnova M, Bradl M, Forrester JV. CD34 + corneal stromal cells are bone marrow-derived and express hemopoietic stem cell markers. Stem Cells 2005; 23: 507-515.

22 Plskova J, Kuffova L, Holan V, Filipec M, Forrester JV. Evaluation of corneal graft rejection in a mouse model. $\mathrm{Br} J$ Ophthalmol 2002; 86: 108-113.

23 Benichou G, Valujskikh A, Heeger PS. Contributions of direct and indirect $\mathrm{T}$ cell alloreactivity during allograft rejection in mice. J Immunol 1999; 162: 352-358.

24 Game DS, Warrens AN, Lechler RI. Rejection mechanisms in transplantation. Wien Klin Wochenschr 2001; 113: 832-838.

25 Niederkorn JY, Mayhew E. Phenotypic analysis of oral tolerance to alloantigens: evidence that the indirect pathway of antigen presentation is involved. Transplantation 2002; 73 1493-1500.

26 Sano Y, Ksander BR, Streilein JW. Minor H, rather than MHC, alloantigens offer the greater barrier to successful orthotopic corneal transplantation in mice. Transpl Immunol 1996; 4: 53-56.

27 Sano Y, Ksander BR, Streilein JW. Murine orthotopic corneal transplantation in high-risk eyes. Rejection is dictated primarily by weak rather than strong alloantigens. Invest Ophthalmol Vis Sci 1997; 38: 1130-1138.

28 Sano Y, Ksander BR, Streilein JW. Langerhans cells, orthotopic corneal allografts, and direct and indirect pathways of T-cell allorecognition. Invest Ophthalmol Vis Sci 2000; 41: 1422-1431.

29 Sano Y, Streilein JW, Ksander BR. Detection of minor alloantigen-specific cytotoxic T cells after rejection of murine orthotopic corneal allografts: evidence that graft antigens are recognized exclusively via the 'indirect pathway'. Transplantation 1999; 68: 963-970.

30 Leclerc C, Lo-Man R, Charbit A, Martineau P, Clement JM, Hofnung M. Immunogenicity of viral B- and T-cell epitopes expressed in recombinant bacterial proteins. Int Rev Immunol 1994; 11: 123-132.

31 Cserr HF, Knopf PM. Cervical lymphatics, the blood-brain barrier and the immunoreactivity of the brain: a new view. Immunol Today 1992; 13: 507-512.

32 Egan RM, Yorkey C, Black R, Loh WK, Stevens JL, Woodward JG. Peptide-specific T cell clonal expansion in vivo following immunization in the eye, an immuneprivileged site. J Immunol 1996; 157: 2262-2271.

33 Cursiefen C. Immune privilege and angiogenic privilege of the cornea. Chem Immunol Allergy 2007; 92: 50-57.

34 Niederkorn JY. Immune privilege in the anterior chamber of the eye. Crit Rev Immunol 2002; 22: 13-46.

$35 \mathrm{Xu} \mathrm{H}$, Chen M, Reid DM, Forrester JV. LYVE-1-positive macrophages are present in normal murine eyes. Invest Ophthalmol Vis Sci 2007; 48: 2162-2171.

36 Plskova J, Duncan L, Holan V, Filipec M, Kraal G, Forrester JV. The immune response to corneal allograft requires a sitespecific draining lymph node. Transplantation 2002; 73: 210-215.

37 Plskova J, Holan V, Filipec M, Forrester JV. Lymph node removal enhances corneal graft survival in mice at high risk of rejection. BMC Ophthalmol 2004; 4: 3.

38 Kaplan HJ, Stevens TR. A reconsideration of immunological privilege within the anterior chamber of the eye. Transplantation 1975; 19: 203-209.
39 Kaplan HJ, Streilein JW, Stevens TR. Transplantation immunology of the anterior chamber of the eye. II. Immune response to allogeneic cells. J Immunol 1975; 115: 805-810.

40 Stein-Streilein J, Watte C. Cross talk among cells promoting anterior chamber-associated immune deviation. Chem Immunol Allergy 2007; 92: 115-130.

41 Bromley SK, Iaboni A, Davis SJ, Whitty A, Green JM, Shaw AS et al. The immunological synapse and CD28-CD80 interactions. Nat Immunol 2001; 2: 1159-1166.

42 Steinman RM, Hemmi H. Dendritic cells: translating innate to adaptive immunity. Curr Top Microbiol Immunol 2006; 311: 17-58.

43 Bechmann I, Galea I, Perry VH. What is the blood-brain barrier (not)? Trends Immunol 2007; 28: 5-11.

44 Forster $\mathrm{C}$. Tight junctions and the modulation of barrier function in disease. Histochem Cell Biol 2008; 130: 55-70.

45 Sosnova-Netukova M, Kuchynka P, Forrester JV. The suprabasal layer of corneal epithelial cells represents the major barrier site to the passive movement of small molecules and trafficking leukocytes. Br J Ophthalmol 2007; 91: 372-378.

46 Dua HS, McKinnon A, McMenamin PG, Forrester JV. Ultrastructural pathology of the 'barrier sites' in experimental autoimmune uveitis and experimental autoimmune pinealitis. Br J Ophthalmol 1991; 75: 391-397.

47 McMenamin PG, Forrester JV, Steptoe R, Dua HS. Ultrastructural pathology of experimental autoimmune uveitis in the rat. Autoimmunity 1993; 16: 83-93.

48 McMenamin PG, Forrester JV, Steptoe RJ, Dua HS. Ultrastructural pathology of experimental autoimmune uveitis. Quantitative evidence of activation and possible high endothelial venule-like changes in retinal vascular endothelium. Lab Invest 1992; 67: 42-55.

$49 \mathrm{Xu} \mathrm{H}$, Manivannan A, Jiang HR, Liversidge J, Sharp PF, Forrester JV et al Recruitment of IFN-gamma-producing (Th1-like) cells into the inflamed retina in vivo is preferentially regulated by P-selectin glycoprotein ligand 1:P/E-selectin interactions. J Immunol 2004; 172: 3215-3224.

$50 \mathrm{Xu} \mathrm{H}$, Manivannan A, Dawson R, Crane IJ, Mack M, Sharp $\mathrm{P}$ et al Differentiation to the CCR2 + inflammatory phenotype in vivo is a constitutive, time-limited property of blood monocytes and is independent of local inflammatory mediators. J Immunol 2005; 175: 6915-6923.

$51 \mathrm{Xu} \mathrm{H}$, Chen M, Manivannan A, Lois N, Forrester JV. Agedependent accumulation of lipofuscin in perivascular and subretinal microglia in experimental mice. Aging Cell 2008; 7: 58-68.

$52 \mathrm{Xu} \mathrm{H}$, Chen M, Mayer EJ, Forrester JV, Dick AD. Turnover of resident retinal microglia in the normal adult mouse. Glia 2007; 55: 1189-1198.

$53 \mathrm{Xu} \mathrm{H}$, Dawson R, Forrester JV, Liversidge J. Identification of novel dendritic cell populations in normal mouse retina. Invest Ophthalmol Vis Sci 2007; 48: 1701-1710.

54 Forrester JV. Intermediate and posterior uveitis. Chem Immunol Allergy 2007; 92: 228-243.

55 Janeway Jr CA, Medzhitov R. Innate immune recognition. Annu Rev Immunol 2002; 20: 197-216.

56 Banchereau J, Steinman RM. Dendritic cells and the control of immunity. Nature 1998; 392: 245-252.

57 Steinman RM. Lasker Basic Medical Research Award. Dendritic cells: versatile controllers of the immune system. Nat Med 2007; 13: 1155-1159.

58 Steinman RM, Bonifaz L, Fujii S, Liu K, Bonnyay D, Yamazaki $\mathrm{S}$ et al The innate functions of dendritic cells in 
peripheral lymphoid tissues. Adv Exp Med Biol 2005; 560: 83-97.

59 Tang Q, Adams JY, Tooley AJ, Bi M, Fife BT, Serra P et al. Visualizing regulatory $\mathrm{T}$ cell control of autoimmune responses in nonobese diabetic mice. Nat Immunol 2006; 7: 83-92.

60 Zehn D, Bevan MJ. T cells with low avidity for a tissuerestricted antigen routinely evade central and peripheral tolerance and cause autoimmunity. Immunity 2006; 25: 261-270.

61 Lambe T, Leung JC, Ferry H, Bouriez-Jones T, Makinen K, Crockford TL et al Limited peripheral T cell anergy predisposes to retinal autoimmunity. J Immunol 2007; 178: 4276-4283.

62 Koelle DM, Corey L. Herpes simplex: insights on pathogenesis and possible vaccines. Annu Rev Med 2008; 59: 381-395.

63 Griffiths MM, Cannon GW, Corsi T, Reese V, Kunzler K. Collagen-induced arthritis in rats. Methods Mol Med 2007; 136: 201-214.

64 Williams RO. Collagen-induced arthritis in mice. Methods Mol Med 2007; 136: 191-199.

65 Matzinger P. Friendly and dangerous signals: is the tissue in control? Nat Immunol 2007; 8: 11-13.

66 Robertson NJ, Brook FA, Gardner RL, Cobbold SP, Waldmann H, Fairchild PJ. Embryonic stem cell-derived tissues are immunogenic but their inherent immune privilege promotes the induction of tolerance. Proc Natl Acad Sci USA 2007; 104: 20920-20925.

67 Waldmann H, Adams E, Fairchild P, Cobbold S. Infectious tolerance and the long-term acceptance of transplanted tissue. Immunol Rev 2006; 212: 301-313.

68 Cobbold SP, Adams E, Graca L, Daley S, Yates S, Paterson A et al. Immune privilege induced by regulatory $\mathrm{T}$ cells in transplantation tolerance. Immunol Rev 2006; 213: 239-255.

69 Munn DH, Mellor AL. The tumor-draining lymph node as an immune-privileged site. Immunol Rev 2006; 213: 146-158.

70 Stockinger B, Veldhoen M. Differentiation and function of Th17 T cells. Curr Opin Immunol 2007; 19: 281-286.

71 Stockinger B, Veldhoen M, Martin B. Th17 T cells: linking innate and adaptive immunity. Semin Immunol 2007; 19: 353-361.

72 Katsanis N, Venable S, Smith JR, Lupski JR. Isolation of a paralog of the Doyne honeycomb retinal dystrophy gene from the multiple retinopathy critical region on 11q13. Hum Genet 2000; 106: 66-72.

73 Marmorstein L. Association of EFEMP1 with malattia leventinese and age-related macular degeneration: a minireview. Ophthalmic Genet 2004; 25: 219-226.

74 Stone EM, Lotery AJ, Munier FL, Heon E, Piguet B, Guymer $\mathrm{RH}$ et al A single EFEMP1 mutation associated with both Malattia Leventinese and Doyne honeycomb retinal dystrophy. Nat Genet 1999; 22: 199-202.

75 Argraves WS, Greene LM, Cooley MA, Gallagher WM. Fibulins: physiological and disease perspectives. EMBO Rep 2003; 4: 1127-1131.
76 Timpl R, Sasaki T, Kostka G, Chu ML. Fibulins: a versatile family of extracellular matrix proteins. Nat Rev Mol Cell Biol 2003; 4: 479-489.

77 Ambati J, Ambati BK, Yoo SH, Ianchulev S, Adamis AP. Age-related macular degeneration: etiology, pathogenesis, and therapeutic strategies. Surv Ophthalmol 2003; 48: 257-293.

78 Crabb JW, Miyagi M, Gu X, Shadrach K, West KA, Sakaguchi $\mathrm{H}$ et al. Drusen proteome analysis: an approach to the etiology of age-related macular degeneration. Proc Natl Acad Sci USA 2002; 99: 14682-14687.

79 Green WR, Key III SN. Senile macular degeneration: a histopathologic study. Trans Am Ophthalmol Soc 1977; 75 180-254.

80 Zarbin MA. Current concepts in the pathogenesis of agerelated macular degeneration. Arch Ophthalmol 2004; 122: 598-614.

81 Seddon JM, Gensler G, Milton RC, Klein ML, Rifai N. Association between C-reactive protein and age-related macular degeneration. JAMA 2004; 291: 704-710.

82 Anderson DH, Mullins RF, Hageman GS, Johnson LV. A role for local inflammation in the formation of drusen in the aging eye. Am J Ophthalmol 2002; 134: 411-431.

83 Hageman GS, Luthert PJ, Victor Chong NH, Johnson LV, Anderson DH, Mullins RF. An integrated hypothesis that considers drusen as biomarkers of immune-mediated processes at the RPE-Bruch's membrane interface in aging and age-related macular degeneration. Prog Retin Eye Res 2001; 20: 705-732.

84 Vasireddy V, Uchida Y, Salem Jr N, Kim SY, Mandal MN, Reddy GB et al. Loss of functional ELOVL4 depletes very long-chain fatty acids ( $>$ or $=\mathrm{C} 28$ ) and the unique omega$\mathrm{O}$-acylceramides in skin leading to neonatal death. Hum Mol Genet 2007; 16: 471-482.

85 McGeer PL, McGeer EG. Inflammation and the degenerative diseases of aging. Ann N Y Acad Sci 2004; 1035: 104-116.

86 Rakoczy PE, Zhang D, Robertson T, Barnett NL, Papadimitriou J, Constable IJ et al. Progressive age-related changes similar to age-related macular degeneration in a transgenic mouse model. Am J Pathol 2002; 161: 1515-1524.

87 Ambati J, Anand A, Fernandez S, Sakurai E, Lynn BC, Kuziel WA et al An animal model of age-related macular degeneration in senescent $\mathrm{Ccl}$-2- or Ccr-2-deficient mice. Nat Med 2003; 9: 1390-1397.

88 Dithmar S, Sharara NA, Curcio CA, Le NA, Zhang Y, Brown $\mathrm{S}$ et al. Murine high-fat diet and laser photochemical model of basal deposits in Bruch membrane. Arch Ophthalmol 2001; 119: 1643-1649.

89 Forrester JV. Macrophages eyed in macular degeneration. Nat Med 2003; 9: 1350-1351.

90 Simpson E. A historical perspective on immunological privilege. Immunol Rev 2006; 213: 12-22. 